21 Vågerö $\mathrm{D}$, Lundberg $\mathrm{O}$. Health inequalities in Britain and Sweden. Lancet 1989;ii:35-6.

22 Lundberg O. Class and health: comparing Britain and Sweden. Soc Sci Med 1986;23:511-7.

23 Olausson PO, Vågerö D. A Swedish classification into social classes based on census information and comparable to the British classification - a proposal. census information and comparable to the Brit

24 Office of Population Censuses and Surveys. Classification of occupations, 1980. London: HMSO, 1980

25 Adelstein AM, Macdonald Davies I, Weatherall JAC. Perinatal and infant mortality: social and biological factors 1975-77. London: HMSO, 1980. (Studies in Medical and Population Subjects No 41.)

26 Breslow NE, Day NE. Statistical methods in cancer research. Vol 2. The design and analysis of cohort studies. Lyons: International Agency for Research on Cancer, 1987. (IARC scientific publications No 82.)

27 Greenland S. Variance estimators for attributable fraction estimates consistent -in both large strata and sparse data. Statist Med 1987;6:701-8.

28 Rietz E. Sterblichkeit und Todesursachen in den Kindenjahren. Acta Paediatr Scand 1930;9:(Suppl III)
29 Quine S. Problems in comparing findings on social class cross-culturallyapplied to infant mortality (Australia and Britain). Soc Sci Med 1990;30: 1283-8.

30 Illsley R. Comparative review of sources, methodology and knowledge. Soc Sci Med 1990;31:229-36.

31 Szreter SRS. The genesis of the Registrar-General's social classification of occupations. British fournal of Sociology 1984;35:522-46.

32 Wilkinson RG. Income distribution and life expectancy. Br Med f 1992;304: 165-8.

33 Wennemo I. Infant mortality and inequality. A comparison of 18 industrialized countries. Stockholm: Department of Sociology, Stockholm University,

34 Nakamura $Y$, Nagai $M$, Yanagawa $H$. A characteristic change in infan mortality rate decrease in Japan. Public Health 1991;105:145-51.

35 Pharoah POD, Morris JN. Postneonatal mortality. Epidemiol Rev 1979;1 $170-83$.

(Accepted 7 fuly 1992)

\title{
How safe is Scottish hot air?
}

\section{Alastair M Thompson}

Department of Surgery, Raigmore Hospital, Inverness IV2 3UJ Alastair M Thompson, surgical registrar

Correspondence to: Department of Surgery, Royal Infirmary, Edinburgh EH3 9YW.

$B M \mathcal{F}$ 1992;305:691
Modern hot air balloons consist of a gondola, containing the pilot, passengers, and propane fuel tanks, suspended beneath a powerful gas burner that intermittently heats air within a nylon canopy overhead. Since the first flight by a British aeronaut (a former Edinburgh medical student) in 1784 ballooning accidents have continued to make front page news. ${ }^{1}$ However, the accurate documentation of ballooning injuries remains sparse. ${ }^{23}$ Theoretical risks include thermal burns from propane; trauma on falling from the gondola (particularly on take off or landing); hypoxia; and unintentional contact with trees, buildings or overhead electricity wires. This paper records a prospective study of injuries to balloonists based in Scotland to find improvements for safer flying.

\section{Methods and results}

Over an eight year period (1983 to 1991) accidents were documented from the 10 pilots, $100 \mathrm{crew}$, and 15 hot air balloons based annually in Scotland. Minor injuries (such as abrasions, small haematomas, or facial hair loss) are commonplace ${ }^{3}$ and were excluded.

Twelve people were seriously injured on nine flights over the eight years and estimated 2000 hours of flying time (table). Limb and facial injuries were most common. Eight of the injured required hospital treatment, nine were unable to return to work immediately, but all 12 made an eventual recovery and eight flew again.

Eight subjects were injured on landing, and two of the aircraft were destroyed. Six cases $(1,2,3,7,11$, and 12) occurred on landing in mountainous terrain and (like case 10) involved the emergency services. Cases 5 and 6 necessitated enforced landings. All the pilots had less that 500 hours of flying experience, and seven of the nine accidents involved private pilots rather than commercial pilots. In five accidents pilot error and changing weather conditions were considered the major causes of the accident. There were no thermal injuries from the propane fuel.

\section{Comment}

Control over a hot air balloon in flight is limited, with the aircraft prey to the vagaries of the weather. Until recently modern ballooning injuries were poorly documented ${ }^{2}{ }^{3}$ and often sensationalised by the media. Six different Scottish hospitals have treated ballooning injuries in the past decade. The casualties in case 2 (subject multiply injured, rescued unconscious from open water) and case 10 (subject grasped $220 \mathrm{kV}$ overhead power wires) clearly benefited from rapid evacuation and hospital attention. The majority of other injuries were to the limbs, sometimes involving considerable force (case 1), and face. Injuries to the face were due to spectacles (which should be removed before landing) or failure to wear crash helmets. It is notable that most accidents occurred during landing. Flights over mountainous territory should not be undertaken lightly (and accounted for half of the casualties), given the unpredictable weather conditions over often hostile landing terrain. The two young crew who experienced vasovagal attacks on unrelated flights were laid prone in the gondola until they recovered. Neither flight went over 2500 feet above mean sea level and the pilot and other crew remained well; thus hypoxia is unlikely to have contributed to their collapse. $^{2}$

The hot air balloons cited in this series were up to 90000 cubic feet $\left(2550 \mathrm{~m}^{3}\right.$; up to five persons) in size. These are smaller than most commercial passenger carrying balloons, the pilots of which are required to pass regular flight tests, although accidents still occur. ${ }^{45}$ Three private pilots accounted for nine of the 12 cases in this series. Thus potential aeronauts should choose a commercial pilot with a good safety record flying a balloon certified for passenger carrying by the Civil Aviation Authority, wear appropriate safety equipment, and fly in good weather.

1 Balloon crashes. Observer 1992 Jan 12:1.

2 Harding RM, Mills FT. Special forms of flight I: balloons, gliders and hang gliders, $B M \mathcal{F}$ 1983;287:277.

3 Thompson AM. Aviation medicine: balloons. BMf 1983;287:614.

4 Accident incident summary: balloons. Flight Safety Bulletin 1991;27(3):44.

5 Accident incident summary: balloons. Flight Safety Bulletin 1991;27(4):44-

(Accepted 30 fuly 1992)

\begin{tabular}{|c|c|c|c|c|c|c|c|c|c|}
\hline $\begin{array}{l}\text { Case } \\
\text { No }\end{array}$ & $\begin{array}{l}\text { Age range } \\
\text { and sex }\end{array}$ & Injuries & $\begin{array}{c}\text { Hospital } \\
\text { treatment }\end{array}$ & Surgery & $\begin{array}{c}\text { Time off } \\
\text { work }\end{array}$ & Role & $\begin{array}{c}\text { Pilot's } \\
\text { capacity* }\end{array}$ & Phase of flight & Comments \\
\hline 1 & $20-30 M$ & Dislocated elbow, facial lacerations & Yes & Yes & Yes & Pilot ] & & & \\
\hline 2 & $10-20 \mathrm{~F}$ & Fractured ribs, head injury, facial bruising & Yes & No & No & Crew & PPL & Landing. Balloon destroyed & Pilot error in adverse weather: air-sea rescue ( 1 other unhurt) \\
\hline 3 & $10-20 \mathrm{M}$ & Knee haematoma & No & & No & Crew & & & \\
\hline 4 & $50-60 \mathrm{M}$ & Fractured ankle & Yes & No & Yes & Pilot & PPL & Landing & Pliot error \\
\hline 5 & $10-20 \mathrm{M}$ & Vasovagal attack & No & & No & Crew & PPL & Mid-flight & Landed immediately \\
\hline 6 & $10-20 \mathrm{~F}$ & Vasovagal attack & No & & No & Crew & PPL & Mid-flight & Landed immediately \\
\hline 7 & $50-60 \mathrm{~F}$ & Thigh haematoma, facial lacerations & Yes & No & Yes & Passenger & CPL & Landing & Adverse weather. Helicopter rescue ( 2 others unhurt) \\
\hline 8 & $30-40 \mathrm{~F}$ & Facial lacerations and haematoma & No & & Yes & Passenger & CPL & Landing & Passenger disobeyed pilot's landing briefing \\
\hline 9 & $10-20 \mathrm{M}$ & Fractured tibia and fibula & Yes & Yes & Yes & Ground crew & PPL & Mid-flight & Tripped chasing balloon \\
\hline 10 & $30-40 \mathrm{~F}$ & Electrical burns on hands and wrists & Yes & Yes & Yes & Crew & PPL & Take off & Pilot error - flew into power wires ( 2 others unhurt) \\
\hline il & $30-40 \mathrm{M}$ & Thigh haematomas, laceration & Yes & No & Yes & Pilot $\}$ & PPL & Landing. Balloon gondola destroyed & Pilot error in adverse weather \\
\hline 12 & $20-30 \mathrm{M}$ & Severe back muscle spasm (unable to walk) & Yes & No & Yes & & & & \\
\hline
\end{tabular}

